\title{
PENGARUH MOTIVASI DAN SUPERVISI TERHADAP KINERJA GURU DI SMA NEGERI 1 GODEAN TAHUN 2013
}

\author{
Sutarta \\ Dinas Dikpora Kabupaten Sleman \\ sutarta@yahoo.co.id
}

\begin{abstract}
ABSTRAK
Penulis meneliti tentang pengaruh motivasi dan supervisi terhadap kinerja guru di SMA Negeri 1 Godean. Tujuannya untuk menganalisis signifikansi pengaruh motivasi terhadap kinerja, menganalisis signifikansi pengaruh supervisi terhadap kinerja, dan menganalisis signifikansi pengaruh motivasi dan supervisi secara bersama-sama terhadap kinerja guru.

Obyek penelitian adalah SMA Negri 1 Godean dengan subyek semua guru baik guru mata pelajaran maupun guru bimbingan konseling. Pengambilan sampel menggunakan teknik non probability sampling yaitu semua populasi digunakan sebagai sampel. Data yang dikumpulkan adalah data primer berbentuk data kualitatif yang diangkakan/dikuantitatifkan dengan menggunakan kuesioner.

Definisi operasional variabel motivasi diukur menggunakan teori Maslow yang terdiri dari 14 pernyataan, variabel supervisi menggunakan buku kerja pengawas terdiri dari 14 pernyataan, dan variabel kinerja menggunakan penilaian kinerja menurut Supardi terdiri dari 13 pernyataan.

Analisis diskriptif dari ketiga variabel diperoleh rata-rata skor motivasi 3,7655, skor supervisi 4,0418 dan skor kinerja 4,1950 ketiganya berada dalam kriteria tinggi. Hasil olah data menggunakan regresi linear ganda diperoleh : (1) nilai adjusted $R$ square adalah 0,285 artinya sumbangan pengaruh variabel motivasi dan supervisi terhadap variabel kinerja sebesar $28,5 \%$ sedangkan sisanya $71,5 \%$ dipengaruhi oleh variabel lain yang tidak dimasukkan dalam model ini, (2) ada pengaruh signifikan secara parsial antara motivasi dan kinerja sebesar 0,0047 ( $p$ value $=$ 0,047 ), ada pengaruh signifikan secara parsial anatara supervisi dan kinerja sebesar 0,042 ( $p$ value $=0,042)$. Secara bersama-sama ada pengaruh signifkan antara motivasi dan supervisi terhadap kinerja guru di SMA Negeri 1 Godean. Besarnya pengaruh ditunjukkan dengan nilai signifikansi ( $p$ value) sebesar 0,001 .
\end{abstract}

Kata kunci : motivasi, supervisi, kinerja

\section{ABSTRACT}

The writer researched about the influence of motivation and supervision to SMA Negeri 1 Godean's teachers. The purpose of this paper is to analyze the signification of motivation influence to the teachers' job, supervision influence to the job, and motivation and supervision influence all together to the teachers' job.

The object of the research is SMA Negeri 1 Godean with the subject of all teachers' subjects and Guidance and Counselor teachers as well. The sampling is taken by the non probability sampling technique. That is all the population are used as the sampling. The data collected is the prime data is in the form of qualitative which is quantified by using questionnaire.

The operational definition of motivation variable is measured with Maslow Theory which is consisted of 14 statements, supervision variable is measured by using Work Book of Supervisor which is consisted of 14 statements and job variable is measured with the job assessment based on Supardi which is consisted of 13 statements.

The descriptive analysis from the third variables is got the average score of motivation 3,7655 , supervision score 4,0418 and job score 4,1950. All of the third is on the high criteria. The result of the data is processed through multiple Regression linear: these are (1) adjusted R Square value that is 0,285 . It means that the contribution of motivation variable influence and supervision to job variable is $28,5 \%$, while the rest of them is $71,5 \%$ which is influenced by the variable which 
is not included in this model, (2) there is a significant influence partially between motivation and job as much as 0,0047 ( $\mathrm{P}$ value $=0,047$ ), there is a significant influence partially between supervision and job as much as $0,042(\mathrm{P}$ value $=0,042)$ there is a significant influence between motivation and supervision to the job of SMA Negeri 1 Godean's teachers. The amount of the influence is shown with the signification ( $\mathrm{P}$ value) as much as 0,001 .

Keywords: motivation, supervision and job.

\section{Latar Belakang Masalah}

Sebagai pengajar atau pendidik guru merupakan salah satu faktor penentu keberhasilan setiap upaya pendidikan. Kinerja guru dalam merencanakan, melaksanakandan mengevaluasi pembelajaran, merupakan faktor utama dalam pencapaian tujuan pembelajaran, keterampilan peguasaan proses pembelajaran ini sangat erat kaitannya dengan tugas dan tanggung jawab guru sebagai pengajar dan pendidik.

Fenomena yang ada di SMA Negeri 1 Godeanyaitu kinerja guru belum maksimal. Di sekolah terlihat sebagian guru baru melaksanakan tugas mengajar di kelas dan melakukan evaluasi tetapi belum membuat perencanaan dengan baik dan membuat tindak lanjut dari evaluasi yang dilakukan.

Kemungkinan faktor-faktor yang menyebabkan kinerja guru tidak maksmial antara lain motivasi kerja guru rendah. Fenomena ini terlihat antara lain guru belum membuat perangkat pembelajaran dengan lengkap dan benar, mengajar kurang semangat, proses pembelajaran masih berpusat pada guru, metode mengajar belum bervariasi sementara supervisi yang dilakukan oleh Kepala Sekolah maupun Pengawas Sekolah kepada guru belum maksimal.

Berdasarkan kenyataan di atas penulis tertarik untuk mengadakan penelitian dengan judul : Pengaruh Motivasi, dan supervisi terhadap kinerja Guru di SMA Negeri 1 Godean.

\section{Tinjauan Pustaka}

Faktor faktor yang mempengaruhi kinerja guru antara lain motivasi dan supervisi. Moekiyat (2002) mengatakan bahwa motivasi, yaitu suatu daya pendorong atau perangsang untuk melakukan sesuatu. Sedang menurut Yukl (2005) supervisi yaitu memperbaiki kinerja bawahan dengan bekerja bersama mereka untuk menganalisis kekuatan dan kelemahan mereka, memberikan pelatihan, mengembangkan ketrampilan , merencanakan pekerjaan mereka, dan menetapkan sasaran prestasi kerja.

\section{Motivasi}


Istilah motivasi berasal dari bahasa latin yaitu movere yang berarti bergerak. Menurut Gibson (1996) motivasi adalah kekuatan yang mendorong seseorang karyawan yang menimbulkan dan mengarahkan perilaku.Dari pengertian tersebut ada tiga hal yang penting pada motivasi yaitu kekuatan, dorongan dan perilaku.Pengertian ini menjelaskan perbedaan perilaku yang intens sebagai hasil dari motivasi yang tinggi.

Menurut Campbell dalam Gibson (1996) teori motivasi terbagi menjadi dua kategori yaitu :teori kepuasan dan teori proses.

a. Teori Kepuasan adalah teori yang memfokuskan pada faktor-faktor dalam diri seseorang yang mendorong, mengarahkan, dan menghentikan perilaku. Teori ini mencoba untuk menentukan kebutuhan-kebutuhan khusus yang memotivasi orang untuk melakukan sesuatu.

b. Teori Proses adalah teori yang menerangkan dan menganalisis bagaimana perilaku didorong , diarahkan, dipertahankan dan dihentikan.

Kedua teori tersebut sangat penting bagi pemimpin untuk memberikan motivasi kepada bawahan atau pekerja.

Teori isi dan motivasi yang penting dan memiliki dampak pada praktek manajemen anatara lain teori hirarki kebutuhan Maslow(Gibson 1996).

Teori motivasi ini dikemukakan oleh Maslow yang membagi kebutuhan manusia menjadi lima tingkatan yaitu :

a. Kebutuhan fisiologis, yaitu kebutuhan fisik yang berupa makanan, minuman, tempat tinggal, dan sembuh dari rasa sakit. Kebutuhan ini merupakan kebutuhan yang paling mendasar. Oleh karena itu pimpinan perlu memberikan gaji yang layak, perumahan dan asuransi kesehatan kepada para pegawai.

b. Kebutuhan rasa aman dan keselamatan yaitu kebutuhan rasa aman dari ancaman, bahaya, dan kejadian dalam lingkungan kerja. Dalam hal ini pimpinan perlu memberikan asuransi kesehatan, asuransi kecelakaan, dan jaminan hari tua atau dana pensiun.

c. Kebutuhan rasa memiliki, sosial dan kasih sayang, yaitu kebutuhan atas persahabatan, berkelompok, interaksi dan kasih sayang.

Hubungan dengan kebutuhan ini pimpinan perlu mengenal para pegawai sehingga terjalin persaudaraan yang erat dan hubungan yang harmonis di lingkungan kerja. Pimpinan perlu mengkondisikan agar para pegawai dapat bekerja sama dalam kelompoknya dan saling 
membantu antara pegawai yang satu dengan lainnya.

d. Kebutuhan atas penghargaan (esteem), yaitu kebutuhan atas harga diri (selfesteem) dan penghargaan dari pihak lain.

Pimpinan perlu memperhatikan para pegawai atas prestasi kerja yang telah dilakukan, yaitu dengan memberikan penghargaan baik yang berupa materiil seperti uang dan barang maupun dalam bentuk non materiil misalnya pujian.

e. Kebutuhan aktualisasi diri, yaitu kebutuhan untuk memenuhi diri seseorang melalui memaksimumkan penggunaan kemampuan, keahlian dan potensi. Kebutuhan aktualisasi diri seperti mengemukakan ide-ide, memberikan saran dan kritik, mengembangkan potensi secara maksimal.

Dalam hubungan dengan kebutuhan ini pimpinan perlu memberikan kesempatan kepada para pegawai agar dapat mengaktualisasikan dirinya secara baik dan maksimal.

Teori ini beranggapan bahwa orang akan memuaskan tingkat berikutnya apabila tingkat sebelumnya terpenuhi terlebih dahulu, walaupun kenyataan dilapangan tidak mesti demikian.
Dengan demikian seseorang itu mempunyai motivasi kerja yaitu apabila terdapat ciri-ciri sebagai berikut :

a. Kinerjanya tergantung pada usaha dan kemampuan yang dimilikinya.

b. Memiliki kemampuan dalam menyelesaikan tugas-tugas yang sulit.

c. Ingin medapatkan umpan balik yang konkrit setelah menyelesaikan tugas secara optimal, efektif dan efisien.

\section{Supervisi.}

Menurut Yukl (2005) supervisi yaitu memperbaiki kinerja bawahan dengan bekerja bersama mereka untuk menganalisis kekuatan dan kelemahan mereka, memberikan pelatihan, mengembangkan ketrampilan , merencanakan pekerjaan mereka, dan menetapkan sasaran prestasi kerja. Dengan demikian peran atasa/pemimpin dalam memperbaiki bawahan sangat penting karena tidak hanya mengawasi saja tetapi juga sebagai sebagai kolaborator.

Menurut Peraturan Menteri Pendidikan Nasional Nomor 41 Tahun 2007 tentang Standar Proses untuk Satuan Pendidikan Dasar dan Menengah supervisi yang dilakukan yaitu :

a. Supervisi proses pembelajaran dilakukan pada tahap perencanaan, pelaksanaan dan penilaian hasil pembelajaran 
b. Supervise pembelajaran dilakukan dengan cara pemberian contoh, diskusi, pelatihan, dan konsultasi

c. Kegiatan supervisi dilakukan oleh kepala sekolah dan pengawas satuan pendidikan.

Ruang lingkup supervisi meliputi dua hal yaitu supervisi akademik dan manajerial (Sujana, N dkk, 2011 : 11).

a. Supervisi akademik adalah fungsi pengawas yang berkenaan dengan aspek pelaksanaan tugas pembinaan, pemantauan, penilaian dan pelatihan professional guru dalam

merencanakan pembelajaran,

melaksanaakan pembelajaran,

menilai hasil pembelajaran,

membimbing dan melatih peserta didik (5) melaksanakan tugas tambahan.

b. Supervisi manajerial merupakan fungsi yang berkenaan dengan pengelolaan sekolah yang terkait langsung dengan peningkatan efisiensi dan efektivitas sekolah.

Dalam hal ini supervisi yang berkaitan langsung dengan guru yaitu supervisi akademik.

Masih menurut menurut Sujana, N dkk (2011) aspek pelaksanaan tugas pengawas dalam melakukan kegiatan supervisi meliputi : pembinaan, pemantauan, penilaian dan pelatihan profesional guru. a. Pembinaan

Tujuan :

1) Meningkatkan pemahaman kompetensi guru terutama kompetensi pedagogik dan kompetensi professional (Tupoksi guru, Kompetensi guru, pemahaman KTSP)

2) Meningkatkan kemampuan guru dalam pengimplementasian Standar Isi, Standar Proses, Standar Kompetensi Kelulusan dan standar Penilaian (pola pembelajaran KTSP. Pengembangan Silabus dan RPP, pengembangan penilaian, pengembangan bahan ajar, dan penulisan butir soal)

3) Meningkatkan kemampuan guru dalam menyusun Penelitian Tindakan Kelas (PTK)

Ruang lingkup:

1) Melakukan pendampingan dalam meningkatkan kemampuan guru menyusun administrasi perencanaan pembelajaran/program bimbingan.

2) Melakukan pendampingan dalam meningkatkan kemampuan guru dalam proses pelaksanaan pembelajaran/ bimbingan.

3) Melakukan pendampingan membimbing guru dalam meningkatkan kemampuan 
melaksanakan penilaian hasil belajar peserta didik.

4) Melakukan pendampingan dalam meningkatkan kemampuan guru dalam menggunakan media dan sumber belajar.

5) Memberikan masukan kepada guru dalam memanfaatkan lingkungan dan sumber belajar.

6) Memberikan rekomendasi kepada guru mengenai tugas membimbing dan melatih peserta didik.

7) Memberi bimbingan kepada guru dalam menggunakan teknologi informasi dan komunikasi untuk pembelajaran.

8) Memberi bimbingan kepada guru dalam pemanfaatan hasil penilaian untuk perbaikan mutu pendidikan dan pembelajaran/ bimbingan

9) Memberikan bimbingan kepada guru untuk melakukan refleksi hasil-hasil yang dicapainya.

b. Pemantauan

Pelaksanaan Standar Isi, Standar Kompetensi Lulusan, Standar Proses dan Standar Penilaian

c. Penilaian (Kinerja Guru)

1) Merencanakan pembelajaran

2) Melaksanakan pembelajaran

3) Menilai hasil pembelajaran

4) Membimbing dan melatih peserta didik dan
5) Melaksanakan tugas tambahan yang melekat pada pelaksanaan kegiatan pokok sesuai dengan beban kerja guru

d. Pelatihan professional guru

Untuk meningkatkan profesioanisme guru dalam melaksanakan tugasnya ditindaklanjuti dengan kegiatan bimbingan dan pelatihan guru dengan tahapan sebagai berikut :

1) Menyusun program pembimbingan dan pelatihan profesional guru di KKG/MGMP/MGP dan sejeninsnya.

2) Melaksanakan pembimbingan dan pelatihan profesioanl guru.

3) Mengevaluasi hasil pembimbingan dan pelatihan professional guru

4) Melaksanakan pembimbingan dan pelatihan profesioanl guru dalam pelaksanaan penelitihan tindakan kelas.

\section{Kinerja}

Menurut Suyadi, P (1999) performance atau kinerja adalah hasil kerja yang dapat dicapai oleh seseorang atau sekelompok orang dalam suatu organisasi, sesuai dengan wewenang dan tanggung jawab masing-masing dalam rangka mencapai tujuan organisasi bersangkutan secara legal, tidak melanggar hukum dan sesuai dengn moral maupun etika. Dari pengertian ini 
ada empat hal penting dalam kinerja yaitu

; hasil kerja, sesuai dengan tanggung jawab, legal dan beretika

Indikator penilaian prestasi kerja/kinerja menurut Supardi (dalam Supriyadi: 2011) ada tujuh, yaitu :

a. Kualitas kerja

Kualitas kerja meliputi akurasi, ketelitian, kerapian, mempergunakan dan memelihara alat-alat kerja, dan kecakapan dalam bekerja.

b. Kuantitas kerja

Merupakan banyaknya hasil yang diperoleh dari target yang telah ditetapkan sebelumnya.

c. Hubungan kerja

Hubungan kerja dinilai melalui sikap seseorang terhadap sekikeliling tempat kerja.

d. Pengetahuan

Pengetahuan dinilai dari pengetahuan sesuatu hal yang berhubungan dengan tugas dan prosedur kerja, penggunaan alat-alat kerja, maupun kemampuan teknis pekerjaan.

e. Menyesuaikan pekerjaan

Penilaian kinerja yang ditinjau dari kemampuan dalam melaksanakan tugasnya diluar pekerjaannya maupun tugas baru serta kecepatannya dalam berpikir dan bertindak.

f. Kehandalan

Kehandalan diukur dari kemampuan seseorang dalam melaksankan tugas.
Kehandalan ini seperti kehandalan dalam melakukan prosedur, kedisiplinan dan lain-lainnya.

g. Keselamatan kerja

Keselamatan kerja menyangkut perhatian pada keselamatan kerja.

Tugas guru menurut Peraturan Menteri Pendidikan Nasional Nomor 41 Tahun 2007 tentang Standar Proses untuk Satuan Pendidikan Dasar dan Menengah meliputi :

a. Perencanaan Proses Pembelajaran

Perencanaan proses pembelajaran meliputi silabus dan rencana pelaksanaan pembelajaran (RPP).

b. Pelaksanaan Proses Pembelajaran Persyaratan Pelaksanaan proses pembelajaran yaitu :

1) Pengelolaan kelas

2) Pelaksanaan pembelajaran

c. Penilaian Hasil Pembelajaran

Penilaian dilakukan oleh guru terhadap pembelajaran untuk mengukur tingkat pencapaian kompetensi peserta didik, serta digunakan sebagai bahan penyusun laporan kemajuan hasil belajar dan memperbaiki proses pembelajaran.

Pengaruh Motivasi, Supervisi dan Kinerja.

Menurut Gibson (1996) prestasi adalah fungsi dari perkalian antara motivasi (M) dan kemampuan/ ablility 
(A), $\mathrm{p}=\mathrm{MxA}$. Teori ini didasarkan pada keyakinan bahwa kinerja seseoarang akan dipengaruhi oleh perasaan mereka tentang gambaran hasil tindakan yang dilakukan. Seorang guru yang menginginkan kenaikan pangkat akan menunjukkan kinerja yang baik, karena guru menganggap kinerja yang baik akan diakui dan dihargai dengan kenaikan pangkat. Harapan kedua apabila naik pangkat gaji yang diperoleh juga akan naik.

Supervisi dilakukan untuk membantu guru dalam memperbaiki kinerja. Perbaikan kinerja yang dilakukan meliputi perencanaan pembelajaran, proses pembelajaran, maupun penilaian pembelajaran. Tugas lain dalam supervisi yaitu mengawasi guru agar tugas yang dilakukan sesuai dengan ketentuan yang berlaku.

Supervisi dapat meningkatkan kinerja guru, baik dalam perencanaan, pelaksanaan, dan penilaian pembelajaran. Oleh karena itu supervisi yang dilakukan oleh pemimpin semakin sering maka kinerja guru akan semakin meningkat.

\section{Metode Penelitian}

Obyek penelitian adalah SMA Negeri 1 Godean, Sleman Yogyakarta.Subyek penelitian adalah guru SMA Negeri 1 Godean baik guru mata pelajaran maupun guru bimbingan konseling.

Teknik pengambilan sampel yang digunakan dalam penelitian ini adalah teknik non probability sampling dengan sampling jenuh (sensus). Non probability samplingadalah teknik pengambilan sampel yang tidak memberi peluang/kesempatan sama bagi setiap unsur atau anggota populasi untuk dipilih menjadi sampel (Sugiyono;2010) .

Data yang dikumpulkan dalam penelitian ini adalah data primer yang berbentuk angka yang dilakukan dengan dengan cara mengukur menggunakan angket.

Pengukuran variabel motivasi dalam penelitian ini diukur dengan menggunakan teori Maslow yang terdiri dari 14 pernyataan meliputi : kebutuhan fisiologis, kebutuhan rasa aman, kebutuhan sosial, kebutuhan harga diri, dan kebutuhan aktualisasi diri.

Pengukuran supervisi menggunakan Buku Kerja Pengawas (2011) aspek pelaksanaan tugas pengawas dalam melakukan kegiatan supervisi meliputi : pembinaan, pemantauan, penilaian dan pelatihan profesional guru.

Variabel kinerja/prestasi kerja diukur berdasarkan indikator penilaian kinerja/prestasi kerja menurut supardi (dalam Supriyadi: 2011) meliputi : 
kualitas kerja, kuantitas kerja, hubungan kerja, pengetahuan, menyesuaikan pekerjaan, kehandalan, dan keselamatan kerja.

\section{Hasil Penelitian dan Pembahasan}

Kuesioner yang disebarkan sebanyak 42 eksemplar. Kuesioner yang terkumpul sebanyak 41 eksemplar dan tidak kembali sebanyak 1 eksemplar. Kuesioner yang tidak lengkap sebanyak 3 eksemplar, yang lengkap dan dianalisis sebanyak 38 eksemplar.

Hasil olah data variabel motivasi, supervisi, dan kinerja secara bersamasama dapat dilihat pada tabel beerikut ini

Tabel 1. Statistik Diskriptif

Descriptive Statistics

\begin{tabular}{|l|r|r|r|r|r|r|}
\hline & \multicolumn{1}{|c|}{$\mathrm{N}$} & \multicolumn{1}{c|}{ Range } & \multicolumn{1}{c|}{ Minimum } & Maximum & \multicolumn{1}{c|}{ Mean } & Std. Deviation \\
\hline Motivasi & 38 & 2,43 & 2,36 & 4,79 & 3,7655 &, 43260 \\
Supervisi & 38 & 2,00 & 2,93 & 4,93 & 4,0418 &, 34835 \\
Kinerja & 38 & 1,46 & 3,54 & 5,00 & 4,1950 &, 35464 \\
Valid N (lis twise) & 38 & & & & & \\
\hline
\end{tabular}

Skor motivasi, supervisi dan kinerja dikelompokkan menjadi lima kriteria yaitu sangat rendah, rendah, sedang, tinggi, dan sangat tinggi. Dari tabel 1 tampak bahwa skor rata-rata motivasi 3,7655 berada dalam rentang kriteria tinggi $(3,41-4,20)$, maka disimpulkan bahwa rata-rata motivasi guru SMA Negeri 1 Godean adalah tinggi. Skor rata-rata supervisi 4,0418 berada dalam rentang kriteria tinggi $(3,41$ - 4,20), maka disimpulkan bahwa ratarata supervisi tinggi. Skor rata-rata kinerja 4,1950 berada dalam rentang kriteria tinggi $(3,41-4,20)$, maka disimpulkan bahwa rata-rata kinerja guru SMA Negeri 1 Godean adalah tinggi.

Hasil analisis diskriptif profil responden menurut umur, jenis kelamin, tingkat pendidikan, status kepegawaian, masa kerja, dan perolehan tunjangan profesi yaitu sebagai berikut:

\section{Profil Responden Menurut Umur.}

Profil responden menurut umur dapat dilihat pada pabel berikut :

Tabel 2. Profil Responden Menurut Umur

\begin{tabular}{lllllll}
\hline NO & \multirow{2}{*}{$\begin{array}{l}\text { Umur } \\
\text { (th) }\end{array}$} & Banyak & Persen & \multicolumn{3}{l}{ Skor rata-rata } \\
\cline { 5 - 7 } & Nya & Tase & Motivasi & Supervisi & Kinerja \\
$\mathbf{1}$ & $25-29$ & 2 & 5 & 3,75 & 3,93 & 4,12 \\
$\mathbf{2}$ & $30-34$ & 5 & 13 & 3,46 & 3,94 & 4,02 \\
$\mathbf{3}$ & $35-39$ & 2 & 5 & 3,82 & 4,32 & 4,27 \\
$\mathbf{4}$ & $40-44$ & 5 & 13 & 3,93 & 4,31 & 4,23 \\
$\mathbf{5}$ & $>45$ & 24 & 64 & 3,79 & 3,99 & 4,22 \\
\hline
\end{tabular}

Dari tabel 2. responden yang dianalisis umurnya diatas 45 tahun, yaitu sebanyak sebanyak 38 orang paling banyak 24 orang atau sebesar $64 \%$. Rata-rata 
skor motivasi responden tertinggi 3,93 pada umur 40-44 tahun dan terendah 3,46 pada umur 30-34 tahun. Rata-rata skor supervisi responden tertinggi 4,32 pada umur 35-39 tahun dan terendah 3,93 pada umur 25-29 tahun. Rata-rata skor kinerja responden tertinggi 4,27 pada umur 3539 tahun dan terendah 4,02 pada umur 30-34 tahun. Pada umur 30-34 tahun responden mempunyai skor rata-rata motivasi dan kinerja terendah.

Berdasarkan wawancara dan pengamatan, responden mulai menjadi guru setelah lulus dari perguruan tinggi rata-rata yang berumur 25 tahun. Responden pada umur 35-39 tahun atau 40-44 tahun berarti telah menjadi guru minimal selama 10 tahun. Pada umur ini guru telah mantap, percaya diri, stabil, dan produktif dalam melaksanakan tugas. Pada umur ini guru berada pada puncak karir.

\section{Profil Responden Menurut Jenis Kelamin.}

Profil responden menurut jenis kelamin dapa dilihat pada tabel berikut :

Tabel 3. Profil Responden Menurut Jenis Kelamin

\begin{tabular}{|c|c|c|c|c|c|c|}
\hline \multirow[t]{2}{*}{ NO } & \multirow{2}{*}{$\begin{array}{l}\text { Jenis } \\
\text { Kelamin }\end{array}$} & \multirow{2}{*}{$\begin{array}{l}\text { Banyak } \\
\text { Nya }\end{array}$} & \multirow{2}{*}{$\begin{array}{l}\text { Persen } \\
\text { Tase }\end{array}$} & \multicolumn{3}{|c|}{ Skor rata-rata } \\
\hline & & & & Motivasi & Supervisi & Kinerja \\
\hline 1 & Laki-laki & 14 & 37 & 3,83 & 4,04 & 4,18 \\
\hline \multirow[t]{2}{*}{2} & Perempuan & 24 & 63 & 3,73 & 4,04 & 4,20 \\
\hline & Jumlah & 38 & 100 & & & \\
\hline
\end{tabular}

Tabel 3. menunjukkan responden perempuan lebih banyak dari responden laki-lakiyaitu 24 orang atau sebesar 63 $\%$. Skor rata-rata motivasi responden laki-laki lebih tinggi dari perempuan, skor rata-rata supervisi laki-laki dan perempuan sama dan skor rata-rata kinerja lebih tinggi perempuan.

Berdasarkan wawancara dengan beberapa responden , laki-laki mempunyai motivasi yang lebih tinggi dari perempuan, apalagi bila sebagai kepala keluarga. Ia harus memenuhi kebutuhan dirinya sendiri maupun keluarganya dalam hal kebutuhan fisik yang berupa sandang, pangan dan papan, kebutuhan rasa aman dan keselamatan, kebutuhan rasa memiliki dan sosial, kebutuhan atas penghargaan, dan kebutuhan aktualisasi diri. Berdasarkan pengamata di lapangan laki-laki dalam hal mengemukakan ide-ide, memberikan kritik dan saran lebih berani dari pada perempuan.

Laki-laki dan perempuan dalam hal supervisi yang dilakukan oleh kepala sekolah/pengawas mempunyai pengertian dan pendapat yang sama. Kinerja perempuan ternyata lebih tinggi dari lakilaki. Berdasarkan wawancara dan 
pengamatan ternyata perempuan lebih tekun, lebih rapi, lebih cermat dan lebih lengkap dalam melaksanakan tugas.
Profi responden menurut tingkat pendidikan dapat dilihat pada tabel berikut :

\section{Profil Responden Menurut Tingkat}

\section{Pendidikan.}

Tabel 4. Profil Responden Menurut Tingkat Pendidikan

\begin{tabular}{lllllll}
\hline NO & Pendidikan & Banyak & Persen & \multicolumn{2}{l}{ Skor rata-rata } & \\
\cline { 5 - 7 } & & nya & Tase & Motivasi & Supervisi & Kinerja \\
$\mathbf{1}$ & Diploma & 1 & 3 & 3,43 & 3,86 & 4,15 \\
$\mathbf{2}$ & Sarjana (S1) & 36 & 94 & 3,75 & 4,04 & 4,19 \\
$\mathbf{3}$ & Sarjana (S2) & 1 & 3 & 4,79 & 4,21 & 4,54 \\
& Jumlah & 38 & 100 & & & \\
\hline
\end{tabular}

Tabel 4. menunjukkan tingkat pendidikan responden terbanyak berpendidikan sarjana (S1) yaitu 36 atau $94 \%$. Semakin tinggi tingkat pendidikan responden semakin tinggi pula skor ratarata motivasi, supervisi dan kinerja.

Semakin itnggi tingkat pendidikan guru, semakin tinggi motivasinya. Hal ini disebabkan ia mendapatkan gaji yang lebih tinggi, sehingga dapa memenuhi kebutuhan-kebutuhannya.

Berdasarkan pengamatan, bila dilakukan supervisi semakin tinggi tingkat pendidikan guru pada umunya lebih mudah memahami kekurangannya dan segera melakukan perubahanperubahan. Semakin tinggi tingkat pendidikan, semakin tinggi pula kinerjanya. Hal ini disebabkan karena guru yang mempunyai pendidikan tinggi mempunyai ilmu yang lebih banyak dan lebih tinggi, sehingga ia dapat melaksanakan tugas dengan baik.

\section{Profil Responden Menurut Status} Kepegawaian.

Profil responden menurut status kepegawaian dapat dilihat pada tabel berikut :

Tabel 5. Profil Responden Menurut Status Kepegawaian

\begin{tabular}{lllllll}
\hline NO & Status & Banyak & Persen & \multicolumn{3}{l}{ Skor rata-rata } \\
\cline { 5 - 7 } & & nya & Tase & Motivasi & Supervisi & Kinerja \\
\cline { 5 - 7 } $\mathbf{1}$ & PNS & 35 & 92 & 3,82 & 4,05 & 4,21 \\
$\mathbf{2}$ & Bukan PNS & 3 & 8 & 3,12 & 3,93 & 3,97 \\
\hline & Jumlah & 38 & 100 & & & \\
\hline
\end{tabular}

Tabel 5. menunjukkan status kepegawaian sebanyak 35 responden berstatus sebagai pegawai negeri sipil
(PNS) atau $92 \%$, sisanya berstatus bukan PNS. Skor rata-rata motivasi, 
supervisi dan kinerja responden berstatus PNS lebih tinggi dari bukan PNS.

Guru dengan status sebagai PNS mempunyai motivasi dan kinerja lebih tinggi dari guru bukan PNS karena mendapat gaji lebih banyak dari guru yang berstatus bukan PNS, mendapat tunjangan fungsional, mendapat asuransi pensiun, dan mendapat asuransi kesehatan serta karirnya dapat berkembang dan dihargai. Ia juga merasa aman karena tidak mudah dikeluarkan dari guru kecuali melakukan pelanggaran berat . Dimata masyarakat guru berstatus PNS mendapat kedudukan lebih tinggi dari guru yang bukan PNS.

Berdasarkan pengamatan guru PNS bila dilakukan supervisi, mereka menerima dengan baik dan segera melakukan perbaikan dan perubahan.

\section{Profil Renponden Menurut Masa Kerja. \\ Profil Responden menurut masa} kerja dapat dilihat pada tabel berikut :

Tabel 6. Profil Responden Menurut Masa Kerja

\begin{tabular}{lllllll}
\hline NO & $\begin{array}{l}\text { Masa } \\
\text { kerja (th) }\end{array}$ & Banyak & Persen & \multicolumn{3}{l}{ Skor rata-rata } \\
\cline { 5 - 7 } & nya & Tase & Motivasi & Supervisi & Kinerja \\
$\mathbf{1}$ & $1-5$ & 4 & 11 & 3,77 & 3,89 & 4,00 \\
$\mathbf{2}$ & $6-10$ & 5 & 13 & 3,54 & 4,09 & 4,18 \\
$\mathbf{3}$ & $11-15$ & 1 & 3 & 3,86 & 4,93 & 4,00 \\
$\mathbf{4}$ & $16-29$ & 23 & 60 & 3,80 & 4,01 & 4,23 \\
$\mathbf{5}$ & $>30$ & 5 & 13 & 3,83 & 4,10 & 4,22 \\
\hline
\end{tabular}

Tabel 6. menujukkan bahwa masa kerja responden paling banyak berusia 16-29 tahun sebanyak 23 orang atau sebesar 60 $\%$. Skor rata-rata motivasi tertinggi 3,86 responden dengan masa kerja 11-15 tahun dan terendah 3,54 dengan masa kerja 6-10 tahun. Skor rata-rata supervisi tertinggi 4,93 responden dengan masa kerja 11-15 tahun dan terendah 3,89 dengan masa kerja 1-5 tahun.Skor ratarata kinerja tertinggi 4,23 responden dengan masa kerja 16-29 tahun dan terendah 4,00 dengan masa kerja 1-5 tahun dan 11-15 tahun.
Motivasi tertinggi guru dengan masa kerja 11-15 tahun. Berdasarkan wawancara guru pada masa kerja ini guru telah banyak memperoleh pengalaman yang cukup. Bekal pengalaman ini memberikan dorongan semangat dalam melaksanakan tugasnya.

Guru dengan masa kerja 16-29 tahun sangat trampil dalam melaksanakan tugas. Ketrampilan ini diperoleh dari belajar pengalaman dalam melaksanakan tugas yang sudah dilakukan selama masa kerja tersebut. Pada awal guru melaksanakan tugas kinerjanya belum 
tinggi, karena mereka masih belum banyak pengalaman. Ini terjadi pada guru dengan masa kerja 1-5 tahun.

\section{Profil Responden Menurut Perolehan Tunjangan Profesi.}

Profil responden menurut perolehan tunjangan profesi :

Tabel 7. Profil Responden Menurut Perolehan Tunjangan Profesi

\begin{tabular}{|c|c|c|c|c|c|c|}
\hline \multirow{2}{*}{ NO } & \multirow[t]{2}{*}{ TunjanganProfesi } & \multirow{2}{*}{$\begin{array}{l}\text { Banyak } \\
\text { Nya }\end{array}$} & \multirow{2}{*}{$\begin{array}{l}\text { Persen } \\
\text { Tase }\end{array}$} & \multicolumn{3}{|c|}{ Skor rata-rata } \\
\hline & & & & Motivasi & Supervisi & Kinerja \\
\hline 1 & Belumdapat tunjangan & 31 & 82 & 3,54 & 3,94 & 4,04 \\
\hline \multirow[t]{2}{*}{2} & Dapattunjangan & 7 & 18 & 3,82 & 4,06 & 4,23 \\
\hline & Jumlah & 38 & 100 & & & \\
\hline
\end{tabular}

Tabel 7. menunjukkan sebanyak 31 orang atau $82 \%$ responden sudah mendapat tunjangan profesi yang besarnya satu kali gaji pokok . Skor rata-rata motivasi, supervisi dan kinerja responden yang telah mendapat tunjangan profesi lebih tinggi dari responden yang belum dapat tunjangan profesi.

Tunjangan profesi yaitu tunjangan guru sebesar satu kali gaji pokok yang diberikan kepada guru yang memenuhi syarat. Pendapatan mereka lebih banyak dari guru yang belum mendapatkan tunjangan profesi. Berdasarkan pengamatan mereka lebih semangat dalam melaksanakan tugasnya. Tugastugas guru dilaksanakan dengan baik.

Berdasarkan hasil analisisi regresi tampak bahwanilai adjusted $R$ squareadalah 0,285artinya sumbangan pengaruh variabel motivasi dan supervisi terhadap variabel kinerja sebesar 28,5\%, sedangkan sisanya $71,5 \%$ dipengaruhi oleh variabel lain yang tidak dimasukkan dalam model ini.

$$
\text { Hasil uji F (uji koefisien regresi }
$$
secara bersama-sama) yang digunakan untuk menguji signifikansi pengaruh variabel independen motivasi dan supervisi terhadap variabel dependen kinerja. Nilai signifikansi adalah 0,001< 0,05 ini memberikan kesimpulan bahwa ada pengaruh signifikan secara bersamasama antara motivasi dan supervisi terhadap kinerja guru SMA Negeri 1 Godean.

Hasil output uji t dapat dilihat pada tabel berikut :

Tabel 8. Koefisien

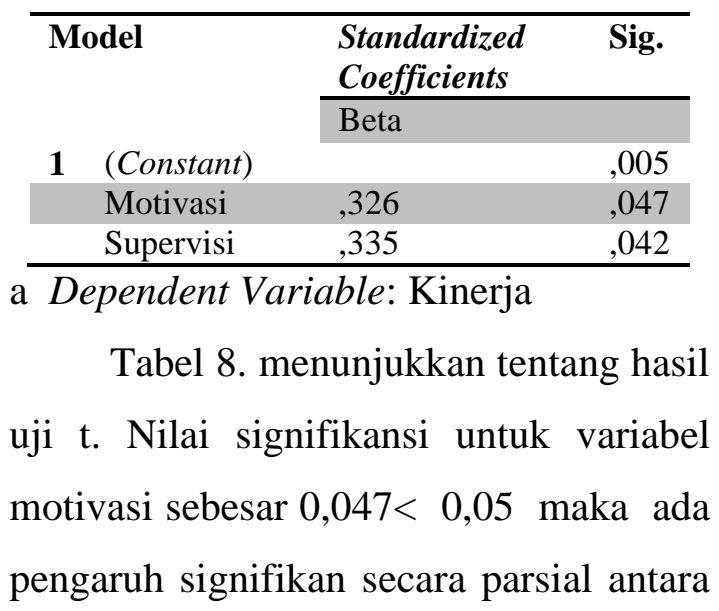


variabel motivasi dan variabel kinerja. Sedangkan untuk variabel supervisi besarnya signifikansi adalah 0,042<0,05 maka ada pengaruh signifikan secara parsial antara variabel supervisi dengan variabel kinerja.

Dari tabel di atas dapat disusun persamaan regresinya yaitu :

$$
\mathrm{Y}=0,326 \mathrm{X}_{1}+0,335 \mathrm{X}_{2}
$$

Kesimpulannya dari analisis di atas yaitu :

1. Ada pengaruh positif signifikan variabel motivasi terhadap kinerja guru di SMA Negeri 1 Godean.

2. Ada pengaruh positif signifikan variabel supervisi terhadap kinerja guru di SMA Negeri 1 Godean.

3. Ada pengaruh positif signifikan variabel motivasi dan supervisi terhadap kinerja guru di SMA Negeri 1 Godean.

Setiap adanya peningkatan motivasi akan diikuti peningkatan kinerja, sebaliknya setiap adanya penurunan motivasi juga akan diikuti penurunan kinerja.

Setiap adanya peningkatan supervisi akan diikuti peningkatan kinerja, sebaliknya setiap adanya penurunan supervisi juga akan diikuti penurunan kinerja.

\section{Kesimpulan}

Berdasarkan analisis data yang telah dilakukan dapat disimpulkan sebagai berikut :

1. Motivasi berpengaruh positif signifikan terhadap kinerja guru di SMA Negeri 1 Godean. Hasil ini menunjukkan bahwa semakin tinggi motivasi guru maka akan semakin tinggi kinerja dan sebaliknya semakin rendah motivasi guru maka akan semakin renda kinerja guru di SMA Negeri 1 Godean.

2. Supervisi berpengaruh positif signifikan terhadap kinerja guru di SMA Negeri 1 Godean. Hasil ini menunjukkan bahwa semakin tinggi supervisi guru maka akan semakin tinggi kinerja dan sebaliknya semakin rendah supervisi maka semakin rendah kinerja guru di SMA Negeri 1 Godean.

3. Motivasi dan supervisi berpengaruh positif signifikan terhadap kinerja guru di SMA Negeri 1 Godean. Hasil ini menunjukkan bahwa semakin tinggi motivasi dan supervisi guru maka akan semakin tinggi kinerja dan sebaliknya semakin rendah motivasi dan supervisi guru maka akan semakin renda kinerja guru di SMA Negeri 1 Godean. 
Pustaka

Depdiknas, “Kumpulan Permendiknas tentang Standar Nasional Pendidikan dan Panduan KTSP”, Jakarta.

Depdiknas, (2007), “Permendiknas no 20 th 2007 tentang Standar Penilaian Pendidikan", Jakarta

Depdiknas, (2007), "Permendiknas no 22 th 2007 tentang Standar Isi”, Jakarta.

Depdiknas, (2007), "Permendiknas no 41 th 2007 tentang Standar Proses untuk Satuan Pendidikan Dasar dan Menengah", Jakarta.

Dirtendik, Depdiknas, (2010), “Supervisi Akademik", Jakarta.

Duwi P, (20120, "Belajar Cepat Olah Data Statistik dengan SPSS", Andi Ofset, Yogyakarta.

Gibson dkk, (1996), "Organisasi”, Binarupa Aksara, Tangerang.

Hamzah B.U. (2007), “Teori Motivasi dan Pengukurannya", PT Bumi Aksara, Jakarta.

Hartono, (2012), “Statistik untuk Penelitian”, Pustaka Pelajar, Yogyakarta.

Heru TK, (2009), "Metode Penelitian Bisnis", Visi Solusi Mandiri, Yogyakarta

Imam G, (2011), “Aplikasi Analisis Multivariate dengan Program IBM SPSS 19", Badan Penerbit
Universitas

Diponegoro,

Semarang.

Nana S, dkk (2011), “ Buku Kerja Pengawas Sekolah", Pusbangtendik Depdiknas, Jakarta.

Ngalim P, (2009), “Administrasi dan Supervisi Pendidikan”, PT Remaja Rosda Karya, Bandung.

Ngalim P, (1990) , "Psikologi Pendidikan”, PT Remaja Rosda Karya, Bandung.

Purwanto, (2011), "Statistik untuk Penelitian”, Pustaka Pelajar.Yogyakarta. Pusbangtendik, (2011), "Buku Kerja Pengawas Sekolah”, Jakarta

Sugiyono, (2010),"'Statistika untuk Penelitian", Alfabeta, Bandung.

Suharsimi A, (2004), “Dasar-dasar Supervisi”, Rineka Cipta, Jakarta. Supriyadi, (2011), "Pengaruh Motivasi terhadap Prestasi Kerja Pegawai dengan Kepribadian sebagai Variabel Moderasi pada Balai Latihan Pendidikan Teknik (BLPT) Yogyakarta", Tesis, UMY, Yogyakarta

Suyadi P, (1999), “Kebijakan Kinerja Karyawan”, BPFE, Yogyakarta 
